\title{
ANEMIA DAN KEJADIAN BERAT BADAN LAHIR RENDAH DI RUMAH SAKIT UMUM ANUTAPURA PALU
}

\section{Anemia and Low Birth Weight in Hospital of Anutapura Palu}

\author{
A. Fahira Nur*1 \\ ${ }^{1 .}$ Bagian Kebidanan, Program Studi DIII Kebidanan STIKES Widya Nusantara, Indonesia
}

Diterima: 24 November 2018; Revisi: 06 Desember 2018; Diterbitkan: 31 Desember 2018

\begin{abstract}
Background \& Objective: Low Birth Weight (BBLR) is a major problem in the world, because it can lead to impaired fetal growth, so that the next generation of the nation will have an effect. This study aims to determine the association of anemia with low birth weight occurrence at hopstilal of Anutapura Palu. Material and Methods: The type of research used is quantitative with analytic observational design with Cross sectional approach. The number of samples is 91 respondents determined by Accidential sampling technique. Data analysis is che-square test with a significance level of $p<0.05$. Results: The results showed that pregnant women who were anemia were $72.5 \%$ and LBW was $40.7 \%$. Severe anemia is $4.39 \%$, moderate is $37.3 \%$, and mild is $30.7 \%$. Anemia level has a significant effect on birth weight $(\rho=$ $0,000)$. Anemia has a significant relationship with the incidence of low birth weight $(\rho=0,000)$ at Hospital of Anutapura Palu . Conclusion: Anemia in pregnant women has a positive correlation with infant birth weight and is associated with the incidence of low birth weight.
\end{abstract}

Keywords: Low Birth Weight, Anemia, Pregnant

Abstrak

Latar Belakang \& Tujuan : Berat Badan Lahir Rendah (BBLR) merupakan masalah yang termasuk besar di dunia, karena dapat mengakibatkan pertumbuhan janin terganggu, sehingga generasi penerus bangsa akan berpengaruh. Penelitian ini bertujuan untuk menganalisis hubungan anemia dengan kejadian berat badan lahir rendah di Rumah Sakit Umum Anutapura Palu. Bahan dan Metode : Jenis penelitian yang digunakan adalah kuantitatif dengan rancangan observasional Analitik dengan pendekatan Cross sectional. Jumlah sampel sebanyak 91 responden yang ditentukan dengan teknik Accidential sampling. Analisis data yaitu uji che-square dengan tingkat signifikansi $\mathrm{p}<0,05$. Hasil : Ibu yang anemia yaitu $72,5 \%$ dan BBLR yaitu 40,7\%. Anemia kategori berat yaitu 4,39\%, sedang yaitu 37,3\%, dan ringan yaitu 30,7\%. Tingkat anemia berpengaruh signifikan terhadap berat badan lahir $(\rho=0,000)$. Anemia memiliki hubungan yang signifikan dengan kejadian berat badan lahir rendah $(\rho=0.000)$ di Rumah Sakit Umum Anutapura Palu. Kesimpulan : Anemia pada ibu hamil memiliki korelasi yang positif terhadap berat badan lahir bayi dan berhubungan dengan kejadian berat badan lahir rendah .

Kata Kunci: Berat Badan Lahir Rendah, Anemia, Ibu Hamil

*Korespondensi: Email : andifahiranur@yahoo.com

\section{PENDAHULUAN}

Berat badan lahir merupakan salah satu indikator kesehatan bayi baru lahir. Rerata berat bayi normal adalah 3200 gram. Secara umum, bayi berat lahir rendah dan bayi dengan berat berlebih lebih besar risikonya untuk mengalami masalah (Damanik,2009). Berdasarkan data gizi global pada tahun 2014, menyatakan bahwa terdapat kasus BBLR sebanyak 20 miliar dengan presentase $15 \%$. Persentase BBLR di negara berkembang adalah 16,5 \% dua kali lebih besar dari pada negara maju (7\%). Indonesia adalah salah satu negara berkembang yang menempati urutan ketiga sebagai negara dengan prevalensi BBLR tertinggi
$(11,1 \%)$, setelah India $(27,6 \%)$ dan Afrika Selatan $(13,2 \%)$ (UNICEF, 2013). Selain itu, Indonesia turut menjadi negara ke dua dengan prevalensi BBLR tertinggi diantara negara ASEAN lainnya, setelah Filipina $(21,2 \%)$ (Depkes RI, 2010).

Dari data Riset Kesehatan Dasar (Riskesdas) tahun 2010 di seluruh Indonesia diperoleh angka kejadian BBLR sebesar 11,1\%. Persentase BBLR tertinggi terdapat di provinsi Sulawesi Tengah $(16,9 \%)$ dan terendah di Sumatera Utara (7,2\%) 
Pada tahun 2013 proporsi BBLR diketahui berdasarkan laporan Dinas Kesehatan/Kota di Sulawesi Tengah yang melaporkan kasus BBLR dengan jumlah 836 kasus, jumlah ini sangat meningkat jika dibandingkan tahun 2012 yaitu 689 kasus. Berdasarkan laporan indikator program gizi dari tiap Kabupaten/Kota di Sulawesi Tengah pada tahun 2014 yang dilaporkan ke Dinas Kesehatan Provinsi Sulawesi Tengah yaitu kasus bayi lahir hidup menderita BBLR berjumlah 877 kasus. Sedangkan pada tahun 2015 kasus BBLR berjumlah 395 bayi, meskipun dari tahun 2015 terjadi penurunan kasus akan tetapi BBLR masih menjadi masalah nomor satu pada AKB (Angka Kematian Bayi) di Indonesia khususnya di Sulawesi Tengah (Dinas Kesehatan Provinsi Sulteng, 2015).

Berdasarkan latar belakang di atas maka tujuan penelitian ini adalah untuk menganalisis hubungan anemia dengan kejadian berat badan lahir rendah di Rumah Sakit Umum Anutapura Palu

\section{BAHAN DAN METODE}

\subsection{Jenis Penelitian}

Jenis penelitian yang digunakan adalah crosectional yang dilaksanakan di Rumah Sakit Anutapuran Kota Palu pada tahun 2017

\subsection{Sampel Penelitian}

Sampel penelitian sejumlah 91 responden pengambilan sampel menggunakan teknik accidental sampling .

\subsection{Pengumpulan Data}

Pengumpulan data yang meliputi kadar hemoglobin ibu hamil dan berat badan lahir bayi pada data rekam medik pasien yang melahirkan di Rumah Sakit Anurapura Kota Palu

\subsection{Analisis Data}

Analisis penelitian menggunakan uji che-square dengan tingkat kemaknaan 5\% $(\mathrm{p}<0,05)$

\section{HASIL}

Tabel 1 menunjukkan bahwa terdapat hubungan yang signifikan anemia dengan kejadian berat badan lahir rendah (BBLR) dengan nilai $\mathrm{p}<0,000$. Ibu yang mengalami anemia pada saat hamil memiliki anak yang sebagian besar mengalami BBLR yaitu 53,0\% sedangkan ibu yang tidak anemia memiliki anak yang tidak BBLR sebesar $92,0 \%$

Tabel 2 menunjukkan bahwa terdapat perbedaan berat badan lahir (BBL) bayi berdasarkan tingkat anemia ibu saat hamil dengan nilai $\mathrm{p}<0,000$. Ibu yang mengalami anemia berat pada saat hamil memiliki BBL terendah dibandingkan dengan ibu yang tidak anemia yaitu $2125 \mathrm{~g}$.

\section{PEMBAHASAN}

Berdasarkan hasil koefisien korelasi tersebut juga dapat diketahui bahwa korelasi bersifat positif, artinya semakin tinggi Berat Badan janin yang dilahirkan maka akan semakin tinggi pula kadar hemoglobin ibu pada trimester 3 di Rumah Sakit Umum Anutapura Palu, dengan memperhatikan nilai koefisien korelasi sebesar 0,409 berarti korelasi yang dilakukan bersifat rendah.

Kadar hemoglobin ibu yang terlalu tinggi menggambarkan keadaan volume plasma yang kurang, vis- kositas darah meningkat sehingga menyebabkan aliran darah kecil terhambat, termasuk yang di plasenta sehingga asupan janin terganggu. Hal ini menyebabkan terjadinya berat lahir yang rendah. Sering dijumpai komplikasi kehamilan berupa pertumbuhan janin terhambat dan fetal distress karena kadar hemoglobin yang terlalu tinggi (Manuba, 2009).

Faktor malnutrisi sebelum dan selama kehamilan mempunyai peranan yang sangat besar dalam kejadian berat bayi lahir rendah (BBLR) dan kematian perinatal. Kekurangan vitamin dan mineral misalnya vitamin A dan Fe dapat menyebabkan anemia pada ibu hamil dan meningkatkan risiko terjadinya infeksi. Infeksi yang disebabkan oleh virus, bakteri,dan parasit yang ada dalam sirkulasi ibu dapat mencapai plasenta dan diteruskan ke sirkulasi janin sehingga menyebabkan persalinan preterm, janin tumbuh lambat, kelainan kongenital, dan kurangnya berat lahir bayi, serta kematian janin dalam rahim (Manuba, 2009)

Selain itu pemberian zat gizi pada janin tergantung dari perfusi darah ibu keplasenta, komposisi darah ibu (kadar Hb dan zat gizi) dan kesanggupan mentransfer nutrien dan oksigen ke janin melewati plasenta. Apabila terjadi anemia pada ibu hamil, maka akan menyebabkan terjadinya gangguan metabolisme dan oksigen asiutero-plasenta yang berakibat pada pertumbuhan janin yang terhambat (PJT) dan berisiko terjadinya berat bayi lahir rendah (BBLR).

Penelitian ini sejalan dengan penelitian yang dilakukan oleh Muazzizah et al (2012) hubungan kadar Hemoglobin ibu hamil dengan Berat Bayi Lahir di RS Permata Bunda kabupaten grobogan menunjukkan bahwa terdapat hubungan antara korelasi kadar hemoglobin ibu hamil dengan berat badan lahir dengan nilai koefisien determinasi sebesar $\mathrm{R}=0,887$, artinya persamaan garis regresi dapat menerangkan 0,887 variasi berat bayi lahir atau persamaan garis yang diperoleh baik untuk menjelaskan variabel berat bayi lahir. Hasil uji statistik menunjukan nilai $p$-value $=0,000(<0,05)$ dapat disimpulkan bahwa regresi sederhana cocok dengan data yang ada dan menolak hipotesis nol, sehingga dapat disimpulkan bahwa antara hemoglobin ibu hamil dengan berat bayi lahir didapatkan hubungan yang signifikan.

Penelitian ini tidak sejalan dengan hasil penelitian yang dilakukan oleh Setiawan et al (2013) yang menunjukkan bahwa tidak ada hubungan yang signifikan antara kadar hemoglobin ibu hamil trimester III dengan berat bayi lahir dengan nilai koefisien korelasi Pearson (R) sebesar $+0,033$, yang menunjukkan derajat hubungan yang sangat lemah dengan tarif signifikani (p) 0,856 (p >0,05).

Nilai rata-rata berat badan lahir yang normal terdapat pada ibu yang mengalami anemia ringan dan tidak anemia dengan berat rata-rata antara 2900 gram sampai dengan 3068 gram dengan standar deviasi 496 gram sampai dengan 487 gram, sedangkan yang mempunyai berat badan lahir rendah terdapat pada ibu yang mempunyai anemia sedang sampai dengan ane- 
mia berat dengan berat rata-rata antara 2125 gram sampai dengan 2376 gram dengan standar deviasi 221 gram sampai dengan 290 gram. Hal ini menunjukkan hasil yang didapatkan pada nilai $\mathrm{p}<0.05$ yang mengindikasikan bahwa terdapat perbedaan yang signifikan pada berat badan bayi yang dilahirkan jika dianalisis dengan tingkat anemia.

Hasil di lapangan didapatkan perbedaan berat badan bayi yang dilahirkan, perbedaan berat sebesar 944 gram pada ibu yang tidak anemia bila dibandingkan dengan ibu yang mengalami anemia berat, perbedaan berat badan bayi sebesar 716 gram pada ibu yang anemia sedang bila dibandingkan dengan ibu yang tidak anemia, dan perbedaan berat sebesar 186 gram pada ibu yang anemia sedang bila dibandingkan dengan ibu yang tidak anemia. Pada ibu hamil dengan kadar hemoglobin tidak normal dan melahirkan bayi dengan berat bayi lahir normal bisa disebabkan karena kekurangan hemoglobinnya tidak terlalu banyak. Kadar hb ibu hamil $10 \mathrm{~g} / \mathrm{dl}$ masih dalam batas normal, risiko terdapat pada kadar hb dibawah $10 \mathrm{~g} / \mathrm{dl}$. Pada penelitian ini diketahui ibu yang melahirkan normal yang mempunyai kadar hb $10 \mathrm{~g} / \mathrm{dl}$ sebanyak 7 orang bayi yang dilahirkan berat badannya normal (Moghaddam, 2015). Bayi yang lahir dengan ibu anemia memiliki berat badan lahir rendah dibandingkan dengan ibu tidak anemia.

Pentingnya kadar hemoglobin normal pada hasil kehamilan. Ada sejumlah besar bukti yang menunjukkan bahwa anemia defisiensi besi pada ibu selama kehamilan dapat mengakibatkan berat badan lahir rendah, wanita hamil dengan kadar hemoglobin kurang dari $10 \mathrm{~g} / \mathrm{dl}$ pada hari pertama dan trimester ketiga dikategorikan sebagai wanita anemia. Wanita dengan anemia selama trimester ketiga kehamilan dan yang memiliki kadar hemoglobin 8.1-10 g/dl,
6.5-8 g/dl dan $<6.5 \mathrm{~g} / \mathrm{dl}$ diklasifikasikan sebagai memiliki anemia ringan, sedang dan berat masingmasing.

Penelitian menunjukkan adanya hubungan anemia dengan berat badan lahir rendah dengan nilai $(\rho=$ $0,000)$. Hal ini menunjukkan bahwa anemia mempunyai hubungan dengan berat badan lahir rendah di $\mathrm{Ru}-$ mah Sakit Anutapura Palu. Hasil dilapangan menunjukkan dari 66 responden yang anemia, terdapat 35 responden $(53,0 \%)$ memiliki berat badan lahir rendah dan 31 responden $(47,0 \%)$ memiliki berat badan lahir normal atau tidak BBLR. Penelitian ini sejalan dengan penelitian Syifaurrahman et al (2016) menunjukkan perbedaan yang bermakna antara berat bayi lahir rendah pada ibu hamil aterm anemia dan tanpa anemia, didapatkan nilai $\mathrm{p}=0.047(\mathrm{p}<0,05)$ dengan rasio prevalensi 1.7 , artinya, terdapat hubungan bermakna antara anemia pada ibu hamil dengan kejadian bayi berat lahir rendah. Ibu hamil dengan anemia 1.7 kali lebih berisiko melahirkan BBLR dibandingkan ibu hamil tanpa anemia. Penelitian ini sejalan dengan penelitian yang dilakukan Yana et al (2016) yang bahwa terdapat hubungan antara status anemia pada saat hamil dengan kejadian BBLR ( $p$-value $=0,006)$.

\section{E. KESIMPULAN}

Anemia pada ibu hamil memiliki hubungan yang signifikan terhadap kejadian berat badan lahir rendah dan ibu hamil yang termasuk kategori anemia yang berat memiliki bayi dengan berat badan lahir yang termasuk rendah dibandingkan dibandingkan dengan ibu yang tidak anemia

\section{F. DAFTAR PUSTAKA}

Damanik, S.M. 2009. Klasifikasi Bayi Menurut Berat Lahir dan Masa Gestasie in Neonatologi, eds M Sholeh K, A Yunanto, R Dewi, G Irawan S, A Usman, IDAI, Jakarta. pp. 12-16.

Depkes RI. 2010. Profil Kesehatan Indonesia. Jakarta:

Tabel 1. Analisis Hubungan Anemia dengan Berat Badan Lahir Rendah di Rumah Sakit Umum Anutapura Palu

\begin{tabular}{|c|c|c|c|c|c|c|c|}
\hline \multirow{3}{*}{ Anemia } & \multicolumn{4}{|c|}{ Kejadian BBLR } & \multirow{2}{*}{\multicolumn{2}{|c|}{ Jumlah }} & \multirow{3}{*}{$\mathbf{p}$} \\
\hline & \multicolumn{2}{|c|}{ BBLR } & \multicolumn{2}{|c|}{ Tidak BBLR } & & & \\
\hline & $\mathrm{n}$ & $\%$ & $\mathrm{n}$ & $\%$ & $\mathrm{~N}$ & $\%$ & \\
\hline $\mathrm{Ya}$ & 35 & 53.0 & 31 & 47.0 & 66 & 100 & \\
\hline Tidak & 2 & 8.0 & 23 & 92.0 & 25 & 100 & 0,000 \\
\hline Jumlah & 37 & 40.7 & 54 & 59.3 & 91 & 100 & \\
\hline
\end{tabular}

Tabel 2. Analisis Pengaruh Tingkat Anemia dengan Berat Badan Lahir di Rumah Sakit Umum Anutapura Palu

\begin{tabular}{|c|c|c|c|c|}
\hline \multirow{2}{*}{ Tingkat Anemia } & \multirow{2}{*}{$\mathbf{N}$} & \multicolumn{2}{|c|}{ Berat Badan Lahir } & \multirow{2}{*}{$\mathbf{p}$} \\
\hline & & Rata-rata & Std. Deviation & \\
\hline Berat & 4 & 2125.00 & 221.736 & \multirow{4}{*}{0,000} \\
\hline Sedang & 34 & 2376.44 & 290.304 & \\
\hline Ringan & 28 & 2900.00 & 496.655 & \\
\hline Tidak Anemia & 25 & 3068.00 & 487.955 & \\
\hline Total & 91 & 2716.47 & 523.513 & \\
\hline
\end{tabular}


Depkes RI.

Dinas Kesehatan Provinsi Sulteng. 2015. Profil Kesehatan Provinsi Sulawesi Tengah.

Manuaba. 2009. Kapita Selekta Penataan Rutin Obstetri Ginekologi dan KB. Jakarta: EGC.

Moghaddam, Tabarizi. (2015). Maternal Hemoglobin Levels during Pregnancy and their Association with Birth Weight of Neonates. Urmia University of Medical Sciences, Urmia, Iran. IRL: PMC4779156

Muazizzah, 2012. Hubungan Kadar Hemoglobin Ibu Hamil Dengan Berat Bayi Lahir Di Rs Permata Bunda Kab.Grobogan Tahun 2011. Universitas Muhamadiyah Semarang. https:// doi.org/10.26714/jk/1.1.2012.73-80.

Riset Kesehatan Dasar. 2013. Badan Penelitian dan Pengembangan Kesehatan. jakarta.

Setiawan, A., Lipoeto, N. I., \& Izzah, A. Z. (2013). Hubungan kadar hemoglobin ibu hamil trimester III dengan berat bayi lahir di Kota Pariaman. Jurnal Kesehatan Andalas, 2(1), 34-37. jurnal.fk.unand.ac.id/index.php/jka/articl e/view/64

Syifaurrahmah, Yusrawati Yusrawati, Zulkarnain Edward. 2016. Hubungan Anemia dengan Kejadian Bayi Berat Lahir Rendah pada Kehamilan Aterm di RSUD Achmad Darwis Suliki. Jurnal Kesehatan Andalas, 5(2).470-474.

United Nation Children Emergency Fund. 2013. Improving Child Nutrition the Achievable Imperative For Global Progress. 3 United Nations Plaza. New York. NY 10017 USA.

Yana, Y., Musafaah, M., Yulidasari, F., 2016. Hubungan Antara Usia Ibu Pada Saat Hamil Dan Status Anemia Dengan Kejadian Berat Badan Lahir Rendah (BBLR) Studi Observasional di Wilayah Kerja Puskesmas Martapura. Jurnal Publikasi Kesehatan Masyarakat Indonesia 3, 20-25 